\title{
Produktivitas Tanaman padi (Oryza sativa L.) cv Segreng Setelah Aplikasi Sludge Biogas di Lahan Sawah Desa Wukirsari, Cangkringan, Sleman
}

\author{
DWI UMI SISWANTI ${ }^{1}$, AKRIMA SYAHIDAH ${ }^{1}$, SUDJINO $^{1}$ \\ ${ }^{1}$ Laboratorium Fisiologi Tumbuhan Fakultas Biologi, Universitas Gadjah Mada \\ Jl. Teknika Selatan, Sekip Utara,Sleman, D.I.Yogyakarta. 55281 \\ Email: dwiumi@ugm.ac.id
}

Received 31 January 2018; Received in revised form 11 February 2018;

Accepted 2 March 2018; Available online 9 May 2018

\begin{abstract}
Rice (Oryza sativa L.) is a main crop agriculture in Indonesia. Biogas sludge is the residue of cattle during processing in the biogas that has lost its gas and rich with macro elements $-\mathrm{N}, \mathrm{P}$ and $\mathrm{K}$ as well as micro elements such as $\mathrm{Ca}, \mathrm{Mg}, \mathrm{Fe}, \mathrm{Mn}, \mathrm{Cu}$ and $\mathrm{Zn}$. Biogas sludge has not been well utilized by the citizens. This study examined the productivity of rice cultivars Segreng to biogas sludge application on field. The objective of this research was to find the best dose of sludge and to study the productivity of rice cultivars Segreng after sludge application on crop field. Research was conducted in $100 \mathrm{~m}^{2}$ of field. The biogas sludge concentration used in this research was 5 variations; (1) $0 \mathrm{ml}$, (2) $1000 \mathrm{ml}$, (3) $2000 \mathrm{ml}$, (4) $3000 \mathrm{ml}$, dan (5) $4000 \mathrm{ml}$. The planting system used is TAJARWO. The productivity parameter measured were Nitrate Reductase Activity (NRA), dry weight, number of grain per plant and grain weight. Environment parameters were temperature, $\mathrm{pH}$, humidity and light intensity. The data was analyzed with ANOVA and followed by DMRT at significant level of 5\%. The results revealed that the highest rice productivity was seen in treatment $2000 \mathrm{ml}$ sludge $/ 100 \mathrm{~m}^{2}$ with $31 \mathrm{gr}$ of dry weight, 483 number of grains per plant and $30.000 \mathrm{~kg} / 100 \mathrm{~m}^{2}$ of grain weight. The best sludge dose present on $2000 \mathrm{ml} / 100 \mathrm{~m}^{2}$.
\end{abstract}

Keywords: biogas, productivity, rice, Segreng, sludge

\section{INTISARI}

Padi (Oryza sativa L.) merupakan salah satu makanan pokok di Indonesia. Desa Wukirsari adalah salah satu penghasil padi terbesar di Kabupaten Sleman. Penurunan produktivitas menjadi kendala serius yang dialami sektor pertanian saat ini, salah satu penyebabnya adalah penggunaan pupuk anorganik yang berlebihan. Salah satu bio organik yang diduga mengandung banyak unsur hara adalah limbah hasil olahan biogas yang disebut sludge. Sludge masih memiliki berbagai unsur hara bermanfaat bagi tanaman. Penelitian menggunakan metode Rancangan Acak Lengkap (RAL), setelah itu data yang diperoleh dianalisis DMRT menggunakan One Way ANOVA pada taraf uji 95\%. Penelitian ini mengkaji produktivitas tanaman padi 'Segreng' akibat aplikasi sludge pada media tanam. Luas lahan yang digunakan dalam penelitian yaitu $500 \mathrm{~m}^{2}$ yang dibagi menjadi 5 petak dengan variasi penambahan sludge biogas $0 \mathrm{ml} / 100 \mathrm{~m}^{2} ; 1000 \mathrm{ml} / 100 \mathrm{~m}^{2} ; 2000 \mathrm{ml} / 100 \mathrm{~m}^{2} ; 3000 \mathrm{ml} / 100$ $\mathrm{m}^{2}$; dan $4000 \mathrm{ml} / 100 \mathrm{~m}^{2}$. Sistem tanam yang digunakan adalah TAJARWO. Saat padi memasuki fase generatif, diuji kadar Aktivitas Nitrat Reduktase (ANR). Setelah padi dipanen, bobot kering tanaman diukur.Selain itu dihitung jumlah kosong ataupun yang berisi. Pengambilan sampel dilakukan dengan 3 ulangan. Hasil yang didapatkan dari penelitian ini produktivitas padi terbaik pada perlakuan sludge $2000 \mathrm{ml} / 100 \mathrm{~m}^{2}$ dengan jumlah bulir 483 biji per rumpun dengan berat $30.000 \mathrm{~kg} / 100 \mathrm{~m}^{2}$. Aktivitas Nitrat Reduktase terbaik didapatkan pada perlakuan sludge $4000 \mathrm{ml} / 100 \mathrm{~m}^{2}$ dengan nilai $1,08 \mu \mathrm{mol}$ $\mathrm{NO}_{2}{ }^{-}$/gram berat basah daun bendera/jam inkubasi.

Kata kunci: biogas, padi, produktivitas, Segreng, sludge 


\section{PENDAHULUAN}

Padi merupakan salah satu komoditas utama pertanian yang dibutuhkan dalam skala besar di Indonesia, terutama di Pulau Jawa. Di Yogyakarta, kebutuhan beras terus menerus mengalami kenaikan akibat pertumbuhan jumlah penduduk, namun tidak diimbangi dengan peningkatan area pertanian dan perbaikan kualitas padi, hal ini menyebabkan penurunan produksi padi. Produksi padi sawah di Yogyakarta mengalami penurunan dari 721.674 ton pada tahun 2013 menjadi 713.800 ton pada tahun 2014 dengan kata lain ada penurunan produktivitas padi sawah dari 6.300 ton/ha menjadi 6.171 ton/ha dalam satu tahun (BPS Daerah Istimewa Yogyakarta, 2015).

Desa Wukirsari, Kecamatan Cangkringan termasuk ke dalam bagian Kabupaten Sleman yang menjadi pemasok beras di Daerah Istimewa Yogyakarta. Secara topografi, desa ini terletak pada ketinggian 450 hingga $600 \mathrm{~m}$ di atas permukaan air laut, dengan curah hujan rata-rata $22 \mathrm{~mm} /$ th. Suhu rata-rata per tahun adalah $21-31^{\circ} \mathrm{C}$. Desa Wukirsari termasuk wilayah yang cocok menjadi wilayah pertanian. Desa Wukirsari terletak di antara Sungai Gendol di sebelah timur dan Sungai Kuning di sebelah barat (RPJM Desa Wukirsari, 2015; Siswanti, 2015).

Sebanyak 2.028 atau 37,68\% warga Desa Wukirsari bermata pencaharian sebagai petani (RPJM Desa, 2015; Siswanti, 2015). Hal ini menjadikan Desa Wukirsari sebagai lumbung padi Kabupaten Sleman yang mendorong "Sleman Swasembada", dengan hasil pertanian sebelum tahun 2010 yang mencapai surplus padi sebanyak 109.724 ton, yang terbagi menjadi 311.378 ton padi sawah dan 1.437 ton padi ladang (Siswanti, 2015).

Penurunan produktivitas menjadi kendala serius yang dialami sektor pertanian saat ini, salah satu penyebabnya adalah penggunaan pupuk anorganik seperti Urea, ZA, TSP/SP-36 dan $\mathrm{KCl}$ (Redono, 2016). Banyaknya kandungan bahan anorganik di dalam tanah mengakibatkan kemampuan tanaman padi untuk membentuk anakan menurun (Sudadi \& Widada, 2001 dalam Redono, 2016). Menurut penelitian Siswanti (2015) lahan pertanian di Kabupaten Sleman, termasuk di Desa
Wukirsari mengandung bahan kimia yang tinggi akibat penggunaan pupuk kimia yang berlebihan $(500 \mathrm{~kg} / \mathrm{ha})$.

Pengembalian produktivitas pertanian yang optimum diperlukan usaha pengembalian senyawa organik tanah yang dapat dilakukan dengan penambahan bahan organik atau penambahan mikrobia berupa pupuk bio organik. Kelebihan penggunaan pupuk organik adalah memperbaiki sifat fisik, kimia dan biologi tanah. Sifat fisik, biologi dan kimia tanah yang membaik meningkatkan produktivitas tanaman pertanian, sehingga memperbaiki kondisi sosial masyarakat melalui peningkatan pendapatan (Siswanti, 2015). Pemupukan merupakan salah satu alternatif untuk meningkatkan kapasitas produksi tanah. Walaupun kandungan unsur hara dalam pupuk organik relatif lebih kecil di banding pupuk anorganik namun bila sifat fisik menjadi baik maka sifat kimia tanah pun akan berubah.

Menurut Siswanti dan Rachmawati (2013), pemberian pupuk bio organik dapat meningkatkan pertumbuhan dan produktivitas padi pada lahan terimbas erupsi Gunung Merapi. Selain itu, pupuk bio organik dapat membantu pengembalian senyawa organik tanah karena mengandung bahan organik atau mikrobia. Pupuk bio organik dapat memperbaiki sifat fisik, kimia, dan biologi tanah sehingga cukup menguntungkan. Salah satu bio organik yang diduga mengandung banyak unsur hara adalah limbah hasil olahan biogas yang disebut sludge. Sludge belum dimanfaatkan dengan baik. Dengan pemberian pupuk organik sludge ini, diharapkan senyawa organik tanah kembali sehingga produksi pertanian dapat meningkat.

Biogas menghasilkan limbah padat cair yaitu berupa kotoran ternak yang telah hilang gasnya dan merupakan pupuk organik yang kaya akan unsur-unsur yang dibutuhkan oleh tanaman seperti protein, selulose, lignin yang tidak bisa digantikan oleh pupuk kimia (Ginting, 2007).Selain nitrogen (N) yang melimpah, sludge juga memiliki kandungan unsur lain seperti fosfor (P), kalium (K), kalsium $(\mathrm{Ca})$, natrium $(\mathrm{Na})$, magnesium $(\mathrm{Mg})$, besi $(\mathrm{Fe})$, dan zinc $(\mathrm{Zn})$. Adanya berbagai 
unsur penting yang terkandung dalam sludge, menjadikan tanaman tumbuh lebih baik dan lebih produktif (Akwaka et al., 2014).

Penelitian ini dilakukan untuk mengetahui pengaruh limbah biogas (sludge biogas) terhadap produktivitas tanaman padi Slegreng di lahan sawah Desa Wukirsari, Kecamatan Cangkringan, Kabupaten Sleman.

\section{METODE}

Penelitian ini dilaksanakan pada bulan Januari sampai April 2017 di sawah Desa Wukirsari,Cangkringan, Sleman. Lahan seluas $500 \mathrm{~m}^{2}$ dibagi menjadi 5 petak dengan variasi penambahan sludge biogas $0 \mathrm{ml} / 100 \mathrm{~m}^{2} ; 1000$ $\mathrm{ml} / 100 \mathrm{~m}^{2} ; 2000 \mathrm{ml} / 100 \mathrm{~m}^{2} ; 3000 \mathrm{ml} / 100$ $\mathrm{m}^{2}$; dan $4000 \mathrm{ml} / 100 \mathrm{~m}^{2}$. Sludge diambil dari reaktor biogas berbahan feses sapi dengan penambahan mikrobia pengurai. Sludge ini merupakan sisa proses produksi gas metan dari reaktor biogas yang otomatis keluar dari reaktor setelah terfermentasi selama 3 hari.

Penanaman dilakukan dengan sistem TAJARWO (Tanam Jajar Legowo) dan setiap lubang diisi satu individu. Pengaturan jarak TAJARWO dengan ukuran $50 \times 25 \mathrm{~cm}$ (ke samping) x $12,5 \mathrm{~cm}$ (ke belakang).
Parameter produktivitas yang diukur pada penelitian ini adalah berat kering, jumlah malai, bulir isi dan Aktivitas Nitrat Reduktase (ANR) pada daun bendera dengan Metode Assay yang telah dimodifikasi (Hartiko, 1983). ANR diukur setelah bunting malai, sedangkan parameter lain diukur setelah panen. Data diuji dengan One Way Anava dilanjutkan dengan uji DMRT dengan taraf signifikansi 95\% $(\alpha=$ $0,05)$. Sedangkan parameter lingkungan yang diukur adalah $\mathrm{pH}$ tanah, suhu tanah, suhu udara, kelembaban tanah dan intensitas cahaya. Parameter lingkungan diukur mulai hari ke-7 setelah tanam ( dihitung sebagai minggu pertama) sampai minggu ke 9 .

\section{HASIL}

Secara umum, pertumbuhan padi optimum di daerah tropis pada suhu antara $20-33^{\circ} \mathrm{C}$. Intensitas cahaya optimum untuk proses fotosintesis adalah 400-1000 lux (Yoshida, 1981). Kelembaban relatif optimum dalam pertumbuhan batang padi adalah sebesar 80$85 \%$, sedangkan pada saat pembungaan adalah sebesar 70-80\% (Sridevi and Chellamuthu, 2015). Hasil pengukuran parameter lingkungan selama 9 minggu terdapat di tabel berikut ini.

Tabel 1. Hasil pengukuran parameter lingkungan

\begin{tabular}{cccccc}
\hline $\begin{array}{c}\text { Mg } \\
\text { ke- }\end{array}$ & Suhu Air $\left({ }^{\circ} \mathbf{C}\right)$ & Suhu Udara $\left({ }^{\circ} \mathbf{C}\right)$ & Intensitas Cahaya (lux) & pH & Klb tnh (\%) \\
\hline 1 & 33 & 31 & 665 & 7 & 55 \\
\hline 2 & 32 & 32 & 730 & 7 & 60 \\
\hline 3 & 29 & 30 & 675 & 7 & 45 \\
\hline 4 & 30 & 32 & 604 & 7 & 30 \\
\hline 5 & 30 & 33 & 706 & 7 & 40 \\
\hline 6 & 27 & 29 & 695 & 7 & 60 \\
\hline 7 & 29 & 29 & 725 & 7 & 65 \\
\hline 8 & 28 & 28 & 610 & 7 & 60 \\
\hline 9 & 27 & 28 & 650 & 7 & 65 \\
\hline
\end{tabular}

Suhu air $27-33^{\circ} \mathrm{C}$ dan suhu udara $28-33^{\circ} \mathrm{C}$, intensitas cahaya yang terukur antara 604-730 lux, $\mathrm{pH}$ tanah 7, dan kelembaban berkisar antara 30-65\%. Hasil pengukuran suhu dan intensitas cahaya yang diperoleh tersebut (Tabel 1) masih termasuk dalam range parameter lingkungan normal. Menurut
Yoshida (1981) suhu normal tanah dan udara di sekitar tanaman padi adalah $27-33^{\circ} \mathrm{C}$. Intensitas cahaya sekitar 600-700 lux. Suhu udara tinggi dapat mempercepat pertumbuhan padi dan proses respirasi, namun apabila terlalu tinggi akan meningkatkan kerusakan tanaman padi. Tanaman padi membutuhkan 
penyinaran sinar matahari penuh dalam pertumbuhannya dan tidak membutuhkan naungan.

Kelembaban tanah juga menjadi faktor penting pertumbuhan padi. Apabila kelembaban rendah saat fase reproduktif dapat menyebabkan pembungaan terhambat. Selain itu, meningkatkan jumlah spikelet yang steril (Sridevi and Chellamuthu, 2015). Keguguran bunga dan buah muda serta kesterilan ini dapat menurunkan produktivitas dari padi. Rendahnya kelembaban tanah ini juga dapat mengganggu pengambilan unsur hara dari tanah terutama $\mathrm{N}$ ke tubuh tumbuhan karena air mempengaruhi keseimbangan dari sel-sel tumbuhan dan berperan dalam pertukaran ionion. Kurangnya unsur $\mathrm{N}$ mengakibatkan menguningnya daun dan gugur daun (Sridevi and Chellamuthu, 2015). Ketersediaan unsur hara dan kemampuan tanaman mengambil unsur hara tersedia yang optimum, berperan dalam memberikan hasil padi terbaik.

Pengukuran parameter produktivitas padi, dilakukan mulai dari awal fase generatif hingga dua pekan setelah panen. Berdasarkan pengamatan dan uji yang telah dilakukan, didapatkan hasil sebagai berikut:

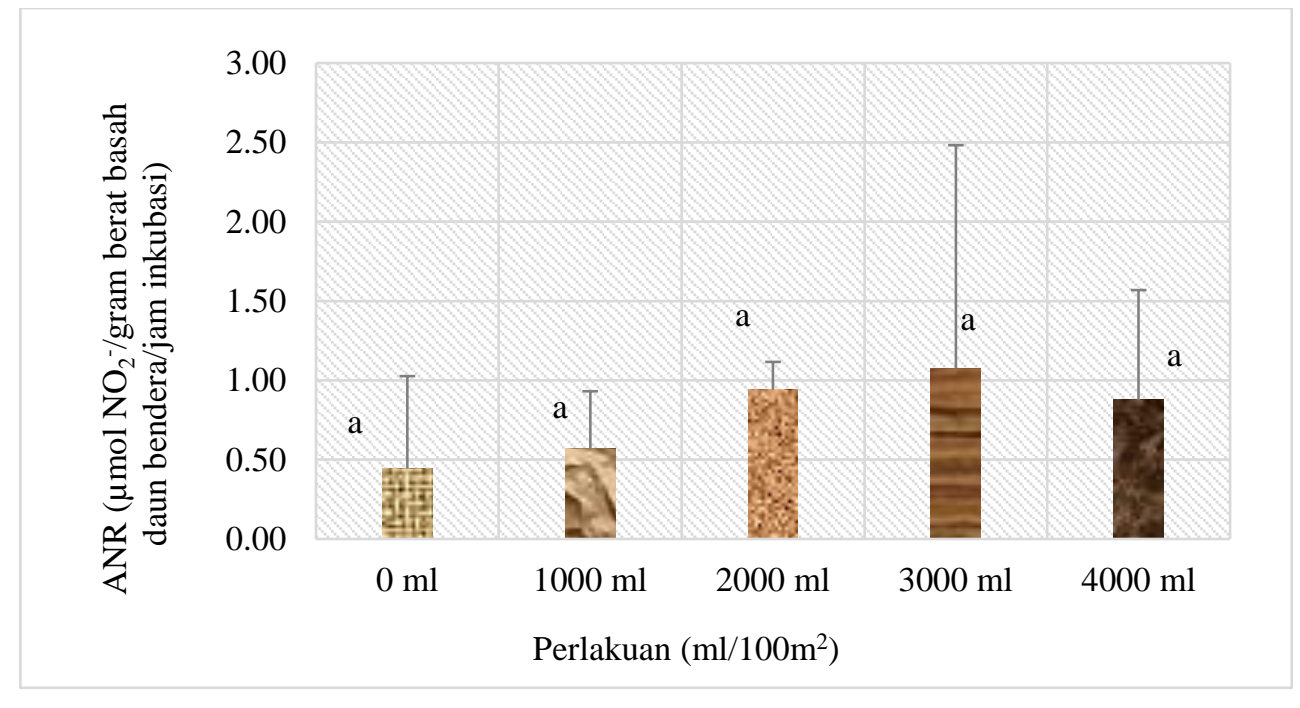

Gambar 1. Pengaruh sludge terhadap ANR

(Ket: Histogram yang diikuti huruf yang sama menunjukkan tidak beda nyata)

Pengambilan daun bendera dilakukan saat bunting malai karena pada saat itu pengambilan unsur hara $\mathrm{N}$ tinggi sehingga metabolisme $\mathrm{N}$ dalam tubuh tanaman berjalan dengan cepat. Jika metabolisme $\mathrm{N}$ berjalan maka kemungkinan tersedianya enzim nitrat reduktase juga tinggi karena nitrat reduktase adalah enzim pertama dalam reduksi nitrat

Uji ANR ketika padi masuk tahap generatif yang ditandai dengan bunting malai. Uji ANR ini dilakukan karena aktivitas dari enzim nitrat reduktase ini dapat menunjukkan laju metabolisme dalam tubuh tumbuhan yang sedang meningkat akibat adanya persiapan molekul pembangun (protein) untuk ditranspor ke bulir padi. Nitrat reduktase merupakan enzim kunci yang pertama kali mengubah ion nitrat yang diserap akar menjadi nitrit, yang selanjutnya akan diubah menjadi amonia. Amonia akan bereaksi dengan glutamin membentuk asam amino glutamat dan membentuk asam amino lain. Asam amino ini digunakan sebagai penyusun sel dan ditranspor menuju bulir padi. Oleh karena itu, menurut Alnopri (2004), kadar ANR biasanya menunjukkan prediksi dari produktivitas padi yang bunting malai.

Kadar ANR tidak berbeda nyata secara signifikan (Gambar. 1) namun menunjukkan peningkatan dari konsentrasi rendah ke tinggi hingga puncaknya ada pada perlakuan 4 yang memiliki nilai $1,08 \mu \mathrm{mol} \mathrm{NO}_{2}{ }^{-}$/gram berat basah daun bendera/jam inkubasi. Akan tetapi, kadar ANR turun pada perlakuan 5. Penurunan kadar ini dapat terjadi karena sludge masih memiliki bakteri baik hasil digester biogas. 
Adanya bakteri dalam sludge yang terlalu berkompetisi untuk memenuhi kebutuhan banyak dengan luasan tanah yang sama menyebabkan bakteri tidak membantu tanaman menyerap unsur hara tanah, namun metabolisme bakteri itu sendiri (Siswanti, 2015).

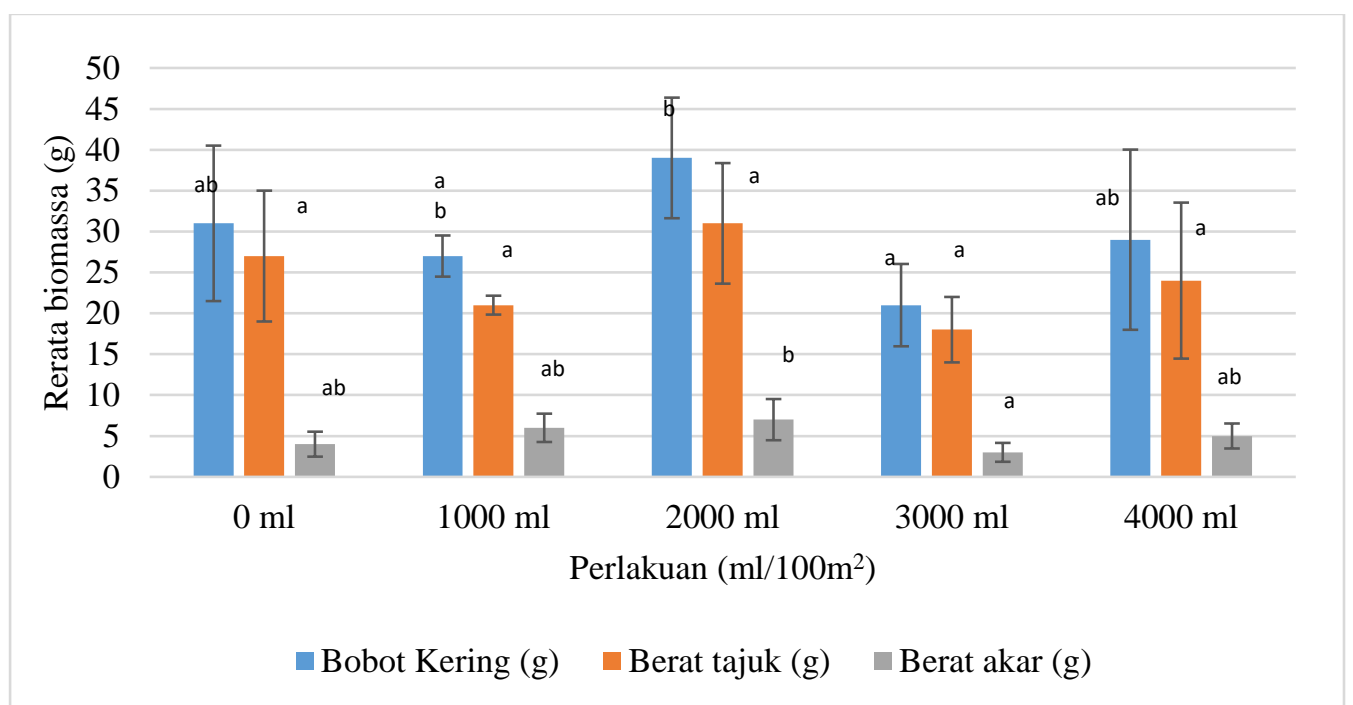

Gambar 2. Pengaruh sludge terhadap bobot kering, berat tajuk dan berat akar padi 'Segreng'.

(Ket: warna histogram yang sama diikuti huruf yang sama menunjukkan tidak beda nyata)

Rerata biomassa padi yang paling tinggi, baik itu berat tajuk, akar, maupun berat kering keseluruhan terdapat pada perlakuan sludge $2000 \mathrm{ml} / 100 \mathrm{~m}^{2}$ dengan berat berturut turut $31 \mathrm{~g}, 8 \mathrm{~g}$, dan 39g. Hasil ANAVA menunjukkan bahwa bobot kering tanaman padi Segreng dengan perlakuan sludge $2000 \mathrm{ml} / 100 \mathrm{~m}^{2}$ tidak memiliki perbedaan yang signifikan dibandingkan dengan perlakuan sludge $0 \mathrm{ml}$, $1000 \mathrm{ml}, 2000$ mldan $4000 \mathrm{ml}$ kecuali dengan perlakuan sludge $3000 \mathrm{ml} / 100 \mathrm{~m}^{2}$.

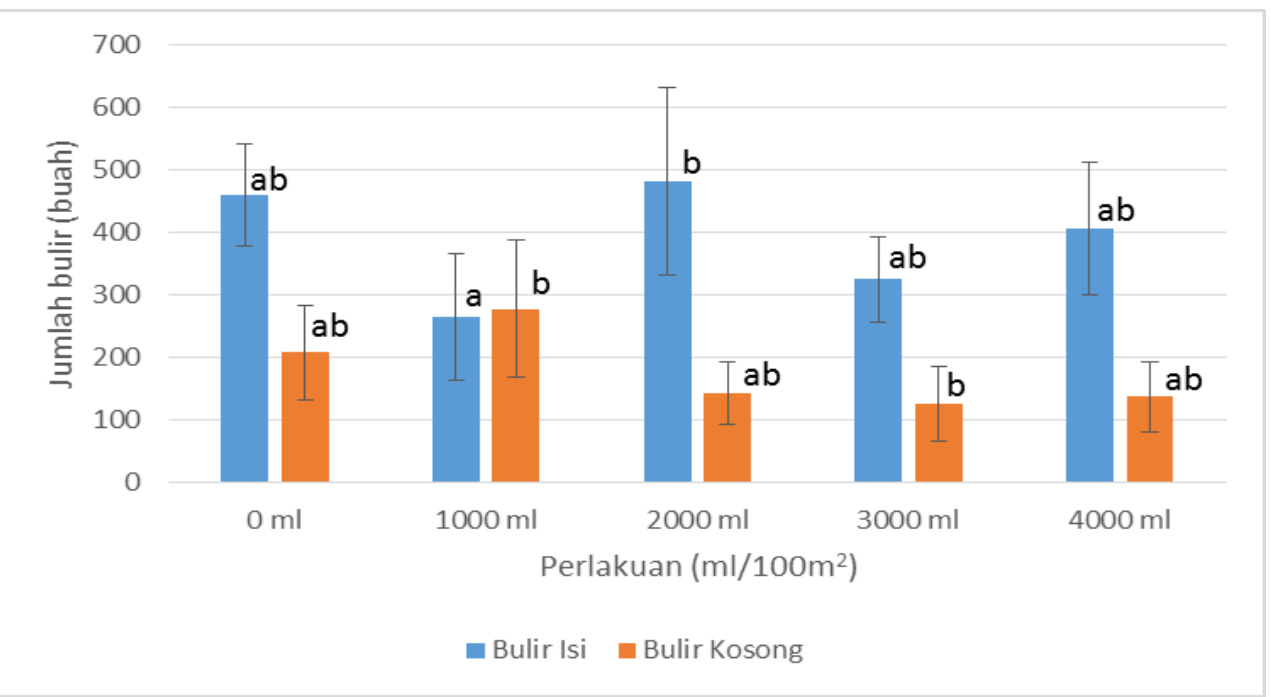

Gambar 3. Pengaruh sludge terhadap rerata jumlah bulir padi

(Ket: warna histogram yang sama diikuti huruf yang sama menunjukkan tidak beda nyata)

Pengukuran biomassa dilakukan terpisah antara bobot kering total, berat tajuk, dan berat akar. Pemisahan ini dilakukan supaya dapat dilihat rasio antara akar dan tajuk yang ideal. Rasio akar dan tajuk ini sering digunakan untuk melihat produktivitas tanaman dari 
proses penyerapan hara oleh akar dan hubungannya dengan pertumbuhan tajuk yang

ada di atasnya. Apabila berat akarnya besar, maka berat tajuk juga meningkat.

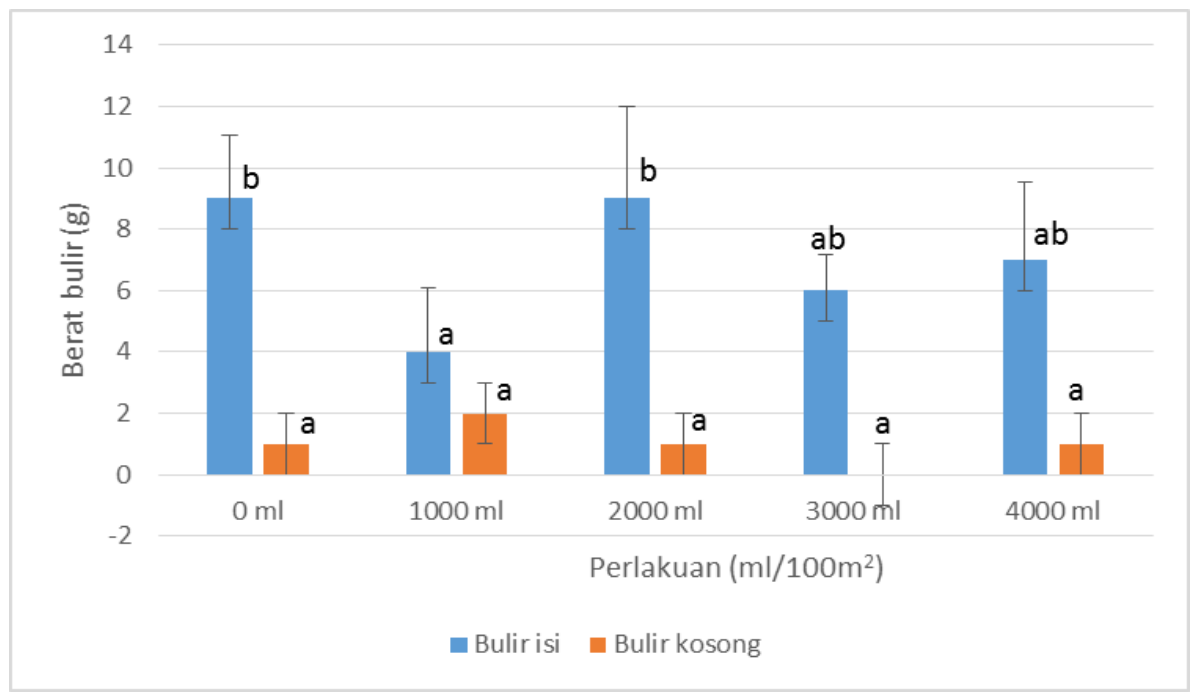

Gambar 5. Pengaruh sludge terhadap rerata berat bulir padi

(Ket: warna histogram yang sama diikuti huruf yang sama menunjukkan tidak beda nyata)

Penghitungan jumlah dan pengukuran berat bulir padi dipisah antara bulir isi dan bulir kosong. Hal ini dilakukan supaya dapat dilihat produktivitas bersih dari panen padi dari jumlah dan berat bulir isi saja. Bulir kosong tetap dihitung dan ditimbang karena dapat menunjukkan adanya produktivitas dari tanaman padi itu sendiri.

Hal yang memungkinkan menjadi penyebab kosongnya bulir adalah kurangnya hasil fotosintesis (fotosintat) untuk disimpan dalam bulir. Perlakuan sludge $2000 \mathrm{ml} / 100 \mathrm{~m} 2$ mempunyai berat bulir isi tertinggi namun tidak berbeda secara signifikan dengan perlakuan sludge $0 \mathrm{ml}, 3000 \mathrm{ml}$ dan $4000 \mathrm{ml}$. Hal ini menunjukkan konsentrasi sludge 2000 $\mathrm{ml} / 100 \mathrm{~m} 2$ mempunyai kemampuan yang sama dengan kontrol pada masa pengisisan bulir. Media dengan penambahan sludge 3000 $\mathrm{ml}$ dan $4000 \mathrm{ml}$ pada masa pengisian bulir memberikan kontribusi hara lebih sedikit dari konsentrasi $2000 \mathrm{ml}$. Hal ini kemungkinan dikarenakan adanya persaingan mikrobia dalam pemanfaatan senyawa dalam sludge.
Rerata jumlah bulir padi terbanyak terdapat pada perlakuan 3 dengan jumlah 483 bulir isi dan 143 bulir kosong, serta berat bulir total $10 \mathrm{~g}$, sedangkan rerata jumlah padi terendah berada pada perlakuan sludge 1000 $\mathrm{ml} / 100 \mathrm{~m}^{2}$ dengan jumlah 266 bulir isi dan 278 bulir kosong. Berdasarkan Gambar 4 dan 5, dapat dilihat bahwa jumlah bulir terbanyak dan berat terbesar ada pada perlakuan sludge 2000 $\mathrm{ml} / 100 \mathrm{~m}^{2}$.

Produktivitas tanaman padi yang paling tinggi juga terdapat pada perlakuan $2000 \mathrm{ml} / 100 \mathrm{~m}^{2}$. Hasil perhitungan jumlah rumpun yang ada dalam luasan $100 \mathrm{~m}^{2}$ adalah 3000 rumpun. Apabila dikonversi keluasan hektar, maka jumlah rumpun yang ada adalah 300.000 rumpun. Perhitungan rumpun ini dilakukan berdasarkan sistem TAJARWO yang memiliki jarak tanam secara pasti sehingga jumlah rumpun yang ada juga bisa dihitung dengan mudah. Rerata berat bulir yang didapatkan selanjutnya dikalikan dengan jumlah rumpun yang ada dan dikonversi ke dalam ton. Hasil yang didapat sebagai berikut:

Tabel 2. Berat bulir padi Slegreng pada perlakuan sludge biogas

\begin{tabular}{ccc}
\hline Perlakuan & Berat bulir/ rumpun $(\mathbf{g})$ & Berat bulir/ha (ton/ha) \\
\hline $\mathbf{1}$ & 10 & 3 \\
\hline $\mathbf{2}$ & 6 & 1,8 \\
\hline $\mathbf{3}$ & 10 & 3 \\
\hline
\end{tabular}




\begin{tabular}{lll}
\hline $\mathbf{4}$ & 6 & 1,8 \\
\hline $\mathbf{5}$ & 8 & 2,4 \\
\hline
\end{tabular}

Produktivitas padi tertinggi adalah 3 ton/ha pada perlakuan kontrol dan perlakuan sludge $2000 \mathrm{ml} / 100 \quad \mathrm{~m}^{2}$, sedangkan produktivitas lebih rendah terdapat pada perlakuan yang lain. Perlakuan kontrol dan perlakuan sludge $2000 \mathrm{ml} / 100 \mathrm{~m}^{2}$ memiliki nilai produktivitas yang sama. Hal ini dapat disebabkan oleh kompetisi mikrobia di dalam media tanahyang mengandung sludge. Akibat kompetisi ini, hara yang terserap oleh akar tidak optimum. Perlakuan sludge $3000 \mathrm{ml}$ dan $4000 \mathrm{ml}$ memiliki produktivitas lebih rendah meskipun diberikan lebih banyak sludge. Berlebihnya sludge yang diberikan dapat mengakibatkan terjadinya kompetisi bakteri dalam mendapatkan nutrien. Nutrien/zat hara untuk pertumbuhan tanaman justru digunakan bakteri untuk memenuhi proses metabolismenya terlebih dahulu. Sedangkan pada perlakuan $1000 \mathrm{ml} / 100 \mathrm{~m}^{2}$ pemberian sludge kemungkinan masih belum mencukupi pasokan nutrien yang dibutuhkan tanaman untuk tumbuh optimal, sehingga pertumbuhannya tidak seoptimal perlakuan sludge $2000 \mathrm{ml} / 100 \mathrm{~m}^{2}$.

\section{KESIMPULAN}

Dosis optimum aplikasi sludge pada padi Segreng adalah $2000 \mathrm{ml} / 100 \mathrm{~m}^{2}$ atau setara dengan 200 liter/ha untuk menghasilkan padi Segreng sejumlah 483 biji per rumpun dengan berat $10 \mathrm{~g} /$ rumpun atau setara dengan 30.000 $\mathrm{kg} / 100 \mathrm{~m}^{2}$. Sedangkan Aktivitas Nitrat Reduktase tertinggi pada perlakuan sludge $3000 \mathrm{ml} / 100 \mathrm{~m}^{2}$.

\section{UCAPAN TERIMAKASIH}

Terima kasih penulis ucapkan kepada LPPM UGM yang telah mendanai penelitian ini, Pak Gandung (pemilik reaktor biogas di Wukirsari) dan Bu Siti (pemilik lahan) serta Tim Sludge: Arianda, Nindy, Mifta dan Akrima.

\section{DAFTAR PUSTAKA}

Akwaka JC, Kukwa DT and Mwekaven SS. 2014. Preliminary study on co-digestion of cow manure with pretreated sawdust for production of biogas and biofertilizer. International Journal of Science and Technology. vol 3(4): 222-228.

Alnopri. 2004. Optimasi prosedur assay Aktivitas Nitrat Reduktase Daun Manggis. Jurnal Akta Agrosia. vol 7(2): 62-66.

BPS Daerah Istimewa Yogyakarta. 2015. https://www.bps.go.id/

Hartiko H. 1983. Leaf and root in vivo nitrate reductase activities of coconut (Cocos nucifera L.) cultivars and hybrids. [Dissertation]. Los Banos: University of the Phillipines. p: 1-32

Redono C. 2016. Respon Petani Terhadap Penggunaan Pupuk Organik Pada Tanaman Padi Sawah di Kelurahan Bokoharjo Kecamatan Prambanan Kabupaten Sleman. Jurnal Agrica Ekstensia. vol. 10(1): 29.

RPJM Desa Wukirsari. 2015. Rencana pembangunan jangka menengah desa (RPJMDes), Wukirsari, Cangkringan, Sleman.

Siswanti DU dan Rachmawati D. 2013. Pertumbuhan tiga kultivar padi (Oryza sativa L.) terhadap aplikasi pupuk bio cair dan kondisi tanah pertanian pasca erupsi merapi 2010. Biogenesis. vol 1(2): 110115.

https://doi.org/10.24252/bio.v1i2.456

Siswanti DU dan Agustin RV. 2014. Respons fisiologis padi (Oryza sativa L.) "Segreng" dan "Menthik Wangi" terhadap aplikasi pupuk organik cair dan dekomposer. Biogenesis. vol 2(2): 89-93. https://doi.org/10.24252/bio.v2i2.472

Sridevi V and Chellamuthu V. 2015. Impact of weather on rice (a review). International Journal of Applied Research. vol 1(9): 825-831.

Yoshida S. 1981. Fundamentals of rice crop science. IRRI. Los Banos, Phillipine, p: 72, 95, 199. 